\title{
Synthesis, crystal structure and photochemistry of Hexakis(butan-1-aminium) heptamolybdate(VI) tetrahydrate
}

\author{
SAVITA S KHANDOLKAR ${ }^{\mathrm{a}}$, ASHISH R NAIK $^{\mathrm{a}}$, CHRISTIAN NÄTHER $^{\mathrm{b}}$, \\ WOLFGANG BENSCH ${ }^{\mathrm{b}}$ and BIKSHANDARKOIL R SRINIVASAN ${ }^{\mathrm{a}, *}$ \\ ${ }^{a}$ Department of Chemistry, Goa University, Goa 403 206, India \\ bInstitut für Anorganische Chemie, Christian-Albrechts-Universität Kiel, Max-Eyth Straße 2, \\ D-24098 Kiel, Germany \\ e-mail: srini@unigoa.ac.in
}

MS received 28 May 2016; revised 9 August 2016; accepted 16 August 2016

\begin{abstract}
The synthesis, crystal structure, spectral characterization, photochemistry, electrochemical and thermal studies of the hexakis(butan-1-aminium) heptamolybdate(VI) tetrahydrate (1) are reported. Dissolution of a mixed mono-hepta compound $\left(\mathrm{BuNH}_{3}\right)_{8}\left[\left(\mathrm{Mo}_{7} \mathrm{O}_{24}\right)\left(\mathrm{MoO}_{4}\right)\right] \cdot 3 \mathrm{H}_{2} \mathrm{O}$ in water results in its transformation to the title compound viz., $\left(\mathrm{BuNH}_{3}\right)_{6}\left[\mathrm{Mo}_{7} \mathrm{O}_{24}\right] \cdot 4 \mathrm{H}_{2} \mathrm{O} 1\left(\mathrm{BuNH}_{3}=\right.$ butan-1-aminium). The structure of the title compound consists of two crystallographically unique $\left[\mathrm{Mo}_{7} \mathrm{O}_{24}\right]^{6-}$ anions, twelve independent $\left(\mathrm{BuNH}_{3}\right)^{+}$ cations and eight unique lattice water molecules, all of which are interlinked with the aid of three varieties of $\mathrm{H}$ bonding interactions. Solar irradiation of $\mathbf{1}$ results in the formation of a bis $\left(\mu_{2}\right.$-oxo $)$ bridged diheptamolybdate product. Electrochemical studies reveal the role of $\mathbf{1}$ in the photodimerization process. Thermal decomposition of 1 results in the formation of crystalline $\alpha-\mathrm{MoO}_{3}$.
\end{abstract}

Keywords. Butan-1-aminium; heptamolybdate; H-bonding interactions; electrochemistry; photodimerization.

\section{Introduction}

Polyoxometalates (POMs) exhibit diverse structures and interesting properties and hence are studied by several researchers. ${ }^{1-9}$ Among the POM's of molybdenum, the structurally flexible heptamolybdate ion $\left[\mathrm{Mo}_{7} \mathrm{O}_{24}\right]^{6-}$ is known to exist in a variety of environments viz., in combination with organic cations ${ }^{10-23}$ and/or metal complex cations. ${ }^{24-28}$ The heptamolybdates (Table 1) in which organic ammonium cations charge balance the $\left[\mathrm{Mo}_{7} \mathrm{O}_{24}\right]^{6-}$ ion exhibit interesting photochemistry. ${ }^{10,11,13,25,30,31}$ A survey of the reported synthetic protocols reveals that heptamolybdates are synthesized by a direct reaction of the commercially available $\left(\mathrm{NH}_{4}\right)_{6}\left[\mathrm{Mo}_{7} \mathrm{O}_{24}\right] \cdot 4 \mathrm{H}_{2} \mathrm{O}$ or $\mathrm{MoO}_{3}$ with an organic amine or an appropriate metal containing reagent. Although some syntheses were performed under hydrothermal conditions ${ }^{12}$ and in a few cases $\mathrm{Na}_{6}\left[\mathrm{Mo}_{7}\right.$ $\left.\mathrm{O}_{24}\right] \cdot 14 \mathrm{H}_{2} \mathrm{O}$ or $\mathrm{Na}_{2} \mathrm{MoO}_{4} \cdot 2 \mathrm{H}_{2} \mathrm{O}$ were employed as a Mo source, ${ }^{21,22,29}$ it is interesting to note that except for the sodium rich $\mathrm{Na}_{7}\left[\mathrm{Mo}_{7} \mathrm{O}_{24}\right] \mathrm{OH} \cdot 21 \mathrm{H}_{2} \mathrm{O}^{26}$ and the mixed monomolybdate-heptamolybdate compound ${ }^{10}$

\footnotetext{
*For correspondence

Dedicated to Prof. Parimal K Bharadwaj on the occasion of his $65^{\text {th }}$ birthday
}

$\left(\mathrm{BuNH}_{3}\right)_{8}\left[\left(\mathrm{Mo}_{7} \mathrm{O}_{24}\right)\left(\mathrm{MoO}_{4}\right)\right] \cdot 3 \mathrm{H}_{2} \mathrm{O}$ 1a $\left(\mathrm{BuNH}_{3}=\right.$ butan1-aminium), the final heptamolybdate product is always isolated from an acidic medium. Earlier, we reported ${ }^{10}$ the structural characterization of a heptamolybdate containing a cocrystallized $\left(\mathrm{MoO}_{4}\right)^{2-}$ ion viz., 1a, which was isolated at a $\mathrm{pH}$ of $\sim 8.0$ by a room temperature reaction of $\mathrm{MoO}_{3}$ with aqueous n-butylamine $\left(\mathrm{BuNH}_{2}\right)$. Prior to our work, Roman et al., ${ }^{16}$ reported only the unit cell but not the atom coordinates of $\left(\mathrm{BuNH}_{3}\right)_{6}\left[\mathrm{Mo}_{7} \mathrm{O}_{24}\right] \cdot 3 \mathrm{H}_{2} \mathrm{O}$ isolated by a reaction of $\mathrm{MoO}_{3}$ with aqueous $\mathrm{BuNH}_{2}$ at $100^{\circ} \mathrm{C}$. In order to determine the structure of a hexakis(butan-1-aminium) heptamolybdate devoid of any $\left(\mathrm{MoO}_{4}\right)^{2-}$ ion, we have investigated the $\mathrm{MoO}_{3} / \mathrm{BuNH}_{2} /$ water reaction system. During the course of these studies, we obtained the title compound $\left(\mathrm{BuNH}_{3}\right)_{6}\left[\mathrm{Mo}_{7} \mathrm{O}_{24}\right] \cdot 4 \mathrm{H}_{2} \mathrm{O} 1$ serendipitously. The results of these investigations are described herein.

\section{Experimental}

\subsection{Materials and methods}

All the chemicals used in this study were of reagent grade and were used as received without any further purification. The known compound $\left(\mathrm{BuNH}_{3}\right)_{8}\left[\mathrm{Mo}_{7} \mathrm{O}_{24}\right]$ 
Table 1. List of structurally characterized heptamolybdate compounds containing organic counterions.

\begin{tabular}{|c|c|c|c|c|}
\hline No & Compound & Space Group & Secondary Interactions & Ref \\
\hline 1 & $\left(\mathrm{H}_{2} \mathrm{DABCO}\right)_{3}\left[\mathrm{Mo}_{7} \mathrm{O}_{24}\right] \cdot 4 \mathrm{H}_{2} \mathrm{O}$ & $C c$ & $\mathrm{O}-\mathrm{H} \cdots \mathrm{O}, \mathrm{N}-\mathrm{H} \cdots \mathrm{O}$ & 11 \\
\hline 2 & $(2-\mathrm{ampH})_{6}\left[\mathrm{Mo}_{7} \mathrm{O}_{24}\right] \cdot 3 \mathrm{H}_{2} \mathrm{O}$ & $P 2_{1} / n$ & $\mathrm{O}-\mathrm{H} \cdots \mathrm{O}, \mathrm{N}-\mathrm{H} \cdots \mathrm{O}$ & $12-14$ \\
\hline 3 & $\left(\mathrm{PyrNH}_{2}\right)_{6}\left[\left(\mathrm{Mo}_{7} \mathrm{O}_{24}\right] \cdot 2 \mathrm{H}_{2} \mathrm{O}\right.$ & $P_{\overline{1}}$ & $\mathrm{O}-\mathrm{H} \cdots \mathrm{O}, \mathrm{N}-\mathrm{H} \cdots \mathrm{O}, \mathrm{C}-\mathrm{H} \cdots \mathrm{O}$ & 10 \\
\hline 4 & $\left(\mathrm{PrNH}_{3}\right)_{6}\left[\mathrm{Mo}_{7} \mathrm{O}_{24}\right] \cdot 3 \mathrm{H}_{2} \mathrm{O}$ & $P_{\overline{1}}$ & $\mathrm{O}-\mathrm{H} \cdots \mathrm{O}, \mathrm{N}-\mathrm{H} \cdots \mathrm{O}$ & 10,15 \\
\hline 5 & $\left(i \mathrm{PrNH}_{3}\right)_{6}\left[\mathrm{Mo}_{7} \mathrm{O}_{24}\right] \cdot 3 \mathrm{H}_{2} \mathrm{O}$ & $P 2 / n$ & $\mathrm{O}-\mathrm{H} \cdots \mathrm{O}, \mathrm{N}-\mathrm{H} \cdots \mathrm{O}$ & 15 \\
\hline 6 & $\left(\mathrm{PentNH}_{3}\right)_{6}\left[\mathrm{Mo}_{7} \mathrm{O}_{24}\right] \cdot 3 \mathrm{H}_{2} \mathrm{O}$ & $P 2_{1} / n$ & $\mathrm{O}-\mathrm{H} \cdots \mathrm{O}, \mathrm{N}-\mathrm{H} \cdots \mathrm{O}$ & 10,16 \\
\hline 7 & $\left(\mathrm{HexNH}_{3}\right)_{6}\left[\mathrm{Mo}_{7} \mathrm{O}_{24}\right] \cdot 3 \mathrm{H}_{2} \mathrm{O}$ & $P 2_{1} / n$ & $\mathrm{O}-\mathrm{H} \cdots \mathrm{O}, \mathrm{N}-\mathrm{H} \cdots \mathrm{O}$ & 10,16 \\
\hline 8 & $\left(\mathrm{BuNH}_{3}\right)_{6}\left[\mathrm{Mo}_{7} \mathrm{O}_{24}\right] \cdot 3 \mathrm{H}_{2} \mathrm{O}^{*}$ & $P_{\overline{1}}$ & & 16 \\
\hline 9 & $\left(\mathrm{t}-\mathrm{BuNH}_{3}\right)_{6}\left[\mathrm{Mo}_{7} \mathrm{O}_{24}\right] \cdot 7 \mathrm{H}_{2} \mathrm{O}$ & $P 2_{1} / n$ & $\mathrm{O}-\mathrm{H} \cdots \mathrm{O}, \mathrm{N}-\mathrm{H} \cdots \mathrm{O}, \mathrm{C}-\mathrm{H} \cdots \mathrm{O}$ & 17 \\
\hline 10 & $\left(\mathrm{TemedH}_{2}\right)_{3}\left[\mathrm{Mo}_{7} \mathrm{O}_{24}\right] \cdot 4 \mathrm{H}_{2} \mathrm{O}$ & $C 2 / c$ & $\mathrm{O}-\mathrm{H} \cdots \mathrm{O}, \mathrm{N}-\mathrm{H} \cdots \mathrm{O}$ & 18 \\
\hline 11 & $(4-\mathrm{apH})_{6}\left[\mathrm{Mo}_{7} \mathrm{O}_{24}\right] \cdot 6 \mathrm{H}_{2} \mathrm{O}$ & $P 2_{1} / c$ & $\mathrm{O}-\mathrm{H} \cdots \mathrm{O}, \mathrm{N}-\mathrm{H} \cdots \mathrm{O}$ & 19 \\
\hline 12 & $\left(\operatorname{dienH}_{3}\right)_{2}\left[\mathrm{Mo}_{7} \mathrm{O}_{24}\right] \cdot 4 \mathrm{H}_{2} \mathrm{O}$ & $C 2 / c$ & $\mathrm{O}-\mathrm{H} \cdots \mathrm{O}, \mathrm{N}-\mathrm{H} \cdots \mathrm{O}, \mathrm{C}-\mathrm{H} \cdots \mathrm{O}$ & 20 \\
\hline 13 & $\left(\mathrm{dienH}_{3}\right)_{2}\left[\mathrm{Mo}_{7} \mathrm{O}_{24}\right] \cdot 4 \mathrm{H}_{2} \mathrm{O}$ & $P 2_{1} / a$ & $\mathrm{O}-\mathrm{H} \cdots \mathrm{O}, \mathrm{N}-\mathrm{H} \cdots \mathrm{O}, \mathrm{C}-\mathrm{H} \cdots \mathrm{O}$ & 20 \\
\hline 14 & $\left(\mathrm{BuNH}_{3}\right)_{8}\left[\left(\mathrm{Mo}_{7} \mathrm{O}_{24}\right)\left(\mathrm{MoO}_{4}\right)\right] \cdot 3 \mathrm{H}_{2} \mathrm{O}$ & $P_{\overline{1}}$ & $\mathrm{O}-\mathrm{H} \cdots \mathrm{O}, \mathrm{N}-\mathrm{H} \cdots \mathrm{O}, \mathrm{C}-\mathrm{H} \cdots \mathrm{O}$ & 10 \\
\hline 15 & $\left(\mathrm{BuNH}_{3}\right)_{6}\left[\mathrm{Mo}_{7} \mathrm{O}_{24}\right] \cdot 4 \mathrm{H}_{2} \mathrm{O}$ & $P 2_{1} / c$ & $\mathrm{O}-\mathrm{H} \cdots \mathrm{O}, \mathrm{N}-\mathrm{H} \cdots \mathrm{O}, \mathrm{C}-\mathrm{H} \cdots \mathrm{O}$ & this work \\
\hline 16 & $\left(\mathrm{GuaNH}_{2}\right)_{6}\left[\mathrm{Mo}_{7} \mathrm{O}_{24}\right] \cdot \mathrm{H}_{2} \mathrm{O}$ & $C 2 / c$ & $\mathrm{O}-\mathrm{H} \cdots \mathrm{O}, \mathrm{N}-\mathrm{H} \cdots \mathrm{O}$ & \\
\hline 17 & $\left(\mathrm{GuaNH}_{2}\right)_{6}\left[\mathrm{Mo}_{7} \mathrm{O}_{24}\right] \cdot \mathrm{H}_{2} \mathrm{O}$ & $P 2_{1} / c$ & $\mathrm{O}-\mathrm{H} \cdots \mathrm{O}, \mathrm{N}-\mathrm{H} \cdots \mathrm{O}$ & 22 \\
\hline 18 & {$[\mathrm{UreaH}]_{3}\left(\mathrm{NH}_{4}\right)_{9}\left[\mathrm{Mo}_{7} \mathrm{O}_{24}\right]_{2} \cdot 5[$ Urea $] \cdot 4 \mathrm{H}_{2} \mathrm{O}$} & $F d d d$ & $\mathrm{O}-\mathrm{H} \cdots \mathrm{O}, \mathrm{N}-\mathrm{H} \cdots \mathrm{O}$ & 23 \\
\hline 19 & {$[2,3-\operatorname{diampH}]_{4}\left[\mathrm{Co}\left(\mathrm{H}_{2} \mathrm{O}\right)_{6}\right]\left[\mathrm{Mo}_{7} \mathrm{O}_{24}\right] \cdot 6 \mathrm{H}_{2} \mathrm{O}$} & $C 2 / c$ & $\mathrm{O}-\mathrm{H} \cdots \mathrm{O}, \mathrm{N}-\mathrm{H} \cdots \mathrm{O}, \mathrm{C}-\mathrm{H} \cdots \mathrm{O}$ & 24 \\
\hline 20 & $(\mathrm{hmtH})_{2}\left[\left\{\mathrm{Mg}\left(\mathrm{H}_{2} \mathrm{O}\right)_{5}\right\}_{2}\left\{\mathrm{Mo}_{7} \mathrm{O}_{24}\right\}\right] \cdot 3 \mathrm{H}_{2} \mathrm{O}$ & $C 2 / c$ & $\mathrm{O}-\mathrm{H} \cdots \mathrm{O}, \mathrm{N}-\mathrm{H} \cdots \mathrm{O}, \mathrm{C}-\mathrm{H} \cdots \mathrm{O}$ & 25 \\
\hline
\end{tabular}

Abbreviations used: $\mathrm{DABCO}=1$,4-diazabicyclo[2.2.2] octane; 2 -amp $=2$-aminopyridine; $\left(\mathrm{PyrNH}_{2}\right)^{+}=$pyrrolidinium; $\mathrm{PrNH}_{2}=$ propan-1-amine; $i \mathrm{PrNH} 2=$ isopropylamine; PentNH $\mathrm{N}_{2}=$ pentan-1-amine; HexNH $2=$ hexan-1-amine; $t \mathrm{BuNH}_{2}=$ tert-butylamine; Temed $=N, N, N, N$,-tetramethylethylenediamine; $\left(\mathrm{GuaNH}_{2}\right)^{+}=$guanidinium; 4-ap $=4$-aminopyridine; dien $=$ diethylentriamine.; 2,3-diamp $=2,3$ diaminopyridine; $\mathrm{BuNH}_{2}=$ butan-1-amine; * Atom coordinates are not reported.

$\left[\mathrm{MoO}_{4}\right] \cdot 3 \mathrm{H}_{2} \mathrm{O} \mathbf{1 a}$ was prepared according to the literature report. ${ }^{10}$ Infrared (IR) spectra of the solid samples diluted with $\mathrm{KBr}$ were recorded on a Shimadzu (IR Prestige-21) FT-IR spectrometer from $4000-400 \mathrm{~cm}^{-1}$ at a resolution of $4 \mathrm{~cm}^{-1}$. Raman spectra of compounds in solid state and in aqueous medium were recorded by using an Agiltron PeakSeeker Pro Raman instrument with $785 \mathrm{~nm}$ laser radiation for excitation and laser power set to $100 \mathrm{~mW}$. The samples for Raman spectra were taken in a quartz cuvette. UV-Visible spectra were recorded using Shimadzu UV-2450 double beam spectrophotometer (200-800 nm) and (Agilent 8453) UVVisible spectrophotometer $(200-1100 \mathrm{~nm})$ in water using quartz cells. Elemental analyses were performed on a Variomicro cube CHNS analyser. X-ray powder patterns were recorded on a Rigaku Miniflex II powder diffractometer using $\mathrm{Cu}-\mathrm{K}_{\alpha}$ radiation with $\mathrm{Ni}$ filter. Simultaneous thermogravimetry (TG) and differential thermal analyses (DTA) of a powdered sample of $\mathbf{1}$ were performed in alumina crucible in the temperature range of $32^{\circ} \mathrm{C}$ to $600^{\circ} \mathrm{C}$, using a Netzsch STA- 409 PC thermal analyser, at a heating rate of $10^{\circ} \mathrm{C} / \mathrm{min}$. Cyclic voltammetry was performed in Electrochemical WorkstationCH Instrument (Inc. CHI6107), under inert atmosphere by using platinum as working electrode, platinum wire as counter electrode and saturated calomel electrode (SCE) as the reference. The redox properties of the aqueous solutions of $\mathbf{1}$ and $\mathbf{1 a}$ were studied using $0.1 \mathrm{M}$
$\mathrm{KNO}_{3}$ solution as supporting electrolyte at a scan rate of $0.03 \mathrm{Vs}^{-1}$ in the potential region 1.0 to $-1.0 \mathrm{~V}$. Conductivity measurements were carried out at room temperature using a digital conductivity meter (LT16) from Labtronics equipped with a standard conductometric cell composed of two platinum black electrodes.

\subsection{Synthesis of hexakis(butan-1-aminium) heptamolybdate(VI) tetrahydrate 1}

The mono-hepta compound $\mathbf{1 a}(2.0 \mathrm{~g})$ was dissolved in distilled water $(10 \mathrm{~mL})$ and the solution was left aside for crystallization. Transparent crystals of $\mathbf{1}$ which formed after 2 days were isolated by filtration followed by washing with ice cold water. The crystals were air dried to obtain $1.70 \mathrm{~g}$ of $\mathbf{1}$ in $\sim 88 \%$ yield with respect to 1a. Anal. Calcd for (1) (\%): C, 18.33; H, 5.13; N, 5.34; Found (\%): C, 18.77; H, 4.78; N, 5.51; IR data $\left(\mathrm{cm}^{-1}\right)$ : 3520, 2980, 2864, 2536, 2091, 1609, 1512, 1460, 1387, 1184, 1087, 1029, 904, 856, 663, 633, 547, 474; Raman data $\left(\mathrm{cm}^{-1}\right): 2967,2933,2918,2879,1441,1079,1049$, 939, 904, 846, 363; UV- Vis data: $208 \mathrm{~nm}(\varepsilon=24.7 \times$ $\left.10^{5} \mathrm{M}^{-1} \mathrm{~cm}^{-1}\right)$; Molar conductivity $\left(\lambda_{\mathrm{m}}\right)(0.02 \mathrm{M}): 375$ $\mathrm{S} \mathrm{cm}{ }^{2} \mathrm{~mol}^{-1}$; DTA $\left({ }^{\circ} \mathrm{C}\right.$ ): 141 (endo), 271 (exo), 453 (exo). 


\section{$2.3 X$-ray crystal structure determination}

The intensity data for $\mathbf{1}$ was collected with an Image Plate Diffraction System (IPDS-1) from STOE. The structure was solved with direct methods using SHELXS- $97^{32}$ and refinement was done against $\mathrm{F}^{2}$ using SHELXL-2014. ${ }^{32}$ All non-hydrogen atoms except some of the disordered $\mathrm{C}$ and $\mathrm{N}$ atoms were refined anisotropically. The $\mathrm{C}-\mathrm{H}$ and $\mathrm{N}-\mathrm{H}, \mathrm{H}$ atoms were positioned with idealized geometry and refined using a riding model. The $\mathrm{O}-\mathrm{H}, \mathrm{H}$ atoms were located in difference map, their bond lengths were set to ideal values and afterwards they were refined using a riding model. Some of the organic cations are disordered and were refined using a split model using restraints (SAME). A numerical absorption correction was performed. Technical details of data acquisition and selected refinement results are listed in (Table 2).

\section{Results and discussion}

\subsection{Crystal structure of $\left(\mathrm{BuNH}_{3}\right)_{6}\left[\mathrm{Mo}_{7} \mathrm{O}_{24}\right] \cdot 4 \mathrm{H}_{2} \mathrm{O}(\mathrm{I})$}

The title compound 1 crystallises in the monoclinic space group $P 2_{1} / c$ with all atoms situated in general positions. Its structure consists of two crystallographically unique $\left[\mathrm{Mo}_{7} \mathrm{O}_{24}\right]^{6-}$ anions (Figure 1), eight independent lattice water molecule and twelve unique $\left(\mathrm{BuNH}_{3}\right)^{+}$ cations five of which are disordered. The metric parameters of the $\left(\mathrm{BuNH}_{3}\right)^{+}$cations are in the normal range. The (Mo-O) bond lengths and (O-Mo-O) bond angles of the unique $\left[\mathrm{Mo}_{7} \mathrm{O}_{24}\right]^{6-}$ anions (Table $\mathrm{S} 1$ in Supplementary Information) agree well with reported data. ${ }^{10,25}$ Both the unique $\left[\mathrm{Mo}_{7} \mathrm{O}_{24}\right]^{6-}$ units are built up of seven edge sharing $\left\{\mathrm{MoO}_{6}\right\}$ octahedra, and are very similar to the heptamolybdate first reported for the ammonium salt by Lindqvist. ${ }^{33}$ It is interesting to note that the presence of lattice water in $\mathbf{1}$ is in accordance with our recent structure analysis of several heptamolybdates. ${ }^{34}$ The lattice water can give rise to interesting water architecture for example in $\left(\mathrm{BuNH}_{3}\right)_{8}\left[\left(\mathrm{Mo}_{7} \mathrm{O}_{24}\right)\left(\mathrm{MoO}_{4}\right)\right]$. $3 \mathrm{H}_{2} \mathrm{O}^{10}$ a water octamer was observed.

An analysis of the crystal structure of $\mathbf{1}$ reveals three varieties of $\mathrm{H}$-bonding interactions namely $\mathrm{N}-\mathrm{H} \cdots \mathrm{O}$, $\mathrm{O}-\mathrm{H} \cdots \mathrm{O}$ and $\mathrm{C}-\mathrm{H} \cdots \mathrm{O}$ among $\left(\mathrm{BuNH}_{3}\right)^{+}$cations, lattice water and the heptamolybdate anions. The $\mathrm{O}$ atoms of the lattice water and the terminal $\mathrm{O}$ atoms of the unique $\left[\mathrm{Mo}_{7} \mathrm{O}_{24}\right]^{6-}$ anions function as $\mathrm{H}$-acceptors. The $\mathrm{H}$-atoms attached to the $\mathrm{O}$ of the lattice water, $\mathrm{N}$ and some $\mathrm{C}$ atoms of the organic cations act as $\mathrm{H}$-donors. The $\mathrm{O}-\mathrm{H} \cdots \mathrm{O}$ interactions among the lattice water molecules $\mathrm{O} 61$ and $\mathrm{O} 62$ result in a water dimer while

Table 2. Crystal data and structure refinement for $\left(\mathrm{BuNH}_{3}\right)_{6}\left[\mathrm{Mo}_{7} \mathrm{O}_{24}\right] \cdot 4 \mathrm{H}_{2} \mathrm{O} \mathbf{1}$.

\begin{tabular}{ll}
\hline Empirical formula & $\mathrm{C}_{24} \mathrm{H}_{80} \mathrm{Mo}_{7} \mathrm{~N}_{6} \mathrm{O}_{28} \mathbf{1}$ \\
\hline Formula weight & 1572.52 \\
Temperature & $170(2) \mathrm{K}$ \\
Wavelength & $0.71073 \AA$ \\
Crystal system, space group & Monoclinic, $P 2_{1} / c$ \\
Unit cell dimensions & $a=21.2962(11) \AA$ \\
& $b=15.8321(9) \AA$ \\
& $c=32.0204(19) \AA$ \\
& $\beta=94.831(7)^{\circ}$ \\
Volume & $10757.8(10) \AA^{3}$ \\
Z, Calculated density & $8,1.942 \mathrm{mg} / \mathrm{m}^{3}$ \\
Absorption coefficient & $1.662 \mathrm{~mm}{ }^{-1}$ \\
F(000) & 6272 \\
Crystal size & $0.12 \times 0.08 \times 0.06 \mathrm{~mm}^{3}$ \\
$\theta$ range for data collection & $1.76^{\circ}$ to $24.97^{\circ}$ \\
Limiting indices & $-25<\mathrm{h} \leq 22,-14 \leq \mathrm{k} \leq 18,-37 \leq 1 \leq 37$ \\
Reflections collected/unique & $47199 / 18450[\mathrm{R}(\mathrm{int})=0.0358]$ \\
Reflections with [I $>2 \sigma(\mathrm{I})]$ & 15276 \\
Min/max transmission & Numerical \\
Refinement method & Full- matrix least-squares on $\mathrm{F}^{2}$ \\
Data/restraints/parameters & $18450 / 11 / 1201$ \\
Goodness of fit on $\mathrm{F}^{2}$ & 1.020 \\
Final R indices [I $>2 \sigma(\mathrm{I})]$ & $\mathrm{R} 1=0.0338, \mathrm{wR} 2=0.0849$ \\
$\mathrm{R}$ indices (all data) & $\mathrm{R} 1=0.0435, \mathrm{wR} 2=0.0893$ \\
Largest diff. peak and hole & 0.779 and $-0.818 \mathrm{e} . \mathrm{A}^{-3}$ \\
\hline & \\
\hline & \\
&
\end{tabular}



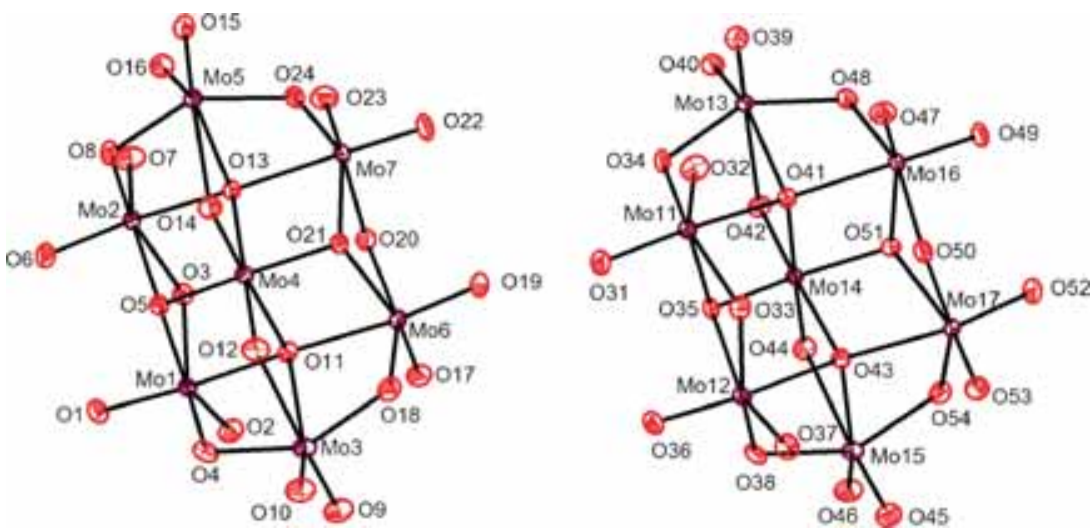

Figure 1. The atom-labelling scheme for the unique $\left[\mathrm{Mo}_{7} \mathrm{O}_{24}\right]^{6-}$ ions in $\mathbf{1}$. Displacement ellipsoids are drawn at $30 \%$ probability level. For clarity, the butan-1-aminium cations and the lattice water molecules (Figure S1) in the crystal structure of $\mathbf{1}$ are not shown.

O63, O64, O65, O66 and O67 form a pentamer (Figure 2). In addition, all eight lattice water molecules viz. dimer, pentamer and $\mathrm{O} 68$ are involved in $\mathrm{O}-\mathrm{H} \cdots \mathrm{O}$ interactions (Table 3 ) with four symmetry related heptamolybdate anions (Figure 2). The $\mathrm{H}$-atoms attached to nitrogen and carbon of organic cations are linked to the heptamolybdate anions and six of the lattice water molecules (O61, O62, O64, O66, O67 and O68) with the aid of $\mathrm{N}-\mathrm{H} \cdots \mathrm{O}$ and $\mathrm{C}-\mathrm{H} \cdots \mathrm{O}$ interactions. In view of the disordered nature of five of the twelve unique $\left(\mathrm{BuNH}_{3}\right)^{+}$cations, a detailed description of the $\mathrm{H}$-bonding situation around organic cations (Table S2) is not given. The net result of the H-bonding interaction is the organization of cations and anions in alternating layers with lattice water serving as links between the two layers (Figure S2).

In a very early study, Yamase ${ }^{30,31}$ explained the mechanism of photoredox process in alkylammonium heptamolybdates revealing the importance of H-bonding interactions. Like several other organic heptamolybdates, the title compound $\mathbf{1}$ also exhibits photochromism (vide infra). An analysis of the secondary interactions in organic heptamolybdates (Table 1) reveals that in many structurally characterized $\left[\mathrm{Mo}_{7} \mathrm{O}_{24}\right]^{6-}$ compounds, three varieties of $\mathrm{H}$-bonds are present as in $\mathbf{1}$.

\subsection{Synthetic aspects, spectral characteristics and thermal studies}

The mixed mono-hepta compound 1a, was used as a precursor for the synthesis of the title heptamolybdate 1 (Scheme 1).

At room temperature $\mathrm{MoO}_{3}$ dissolves in aqueous $\mathrm{BuNH}_{2}$ to form a clear colourless solution ( $\mathrm{pH} \sim 11.4$ ). The Raman spectrum of the reaction mixture (Figure S3) reveals the presence of $\left(\mathrm{MoO}_{4}\right)^{2-}$ ions in solution in the form of an intense band at $892 \mathrm{~cm}^{-1}$ assignable for

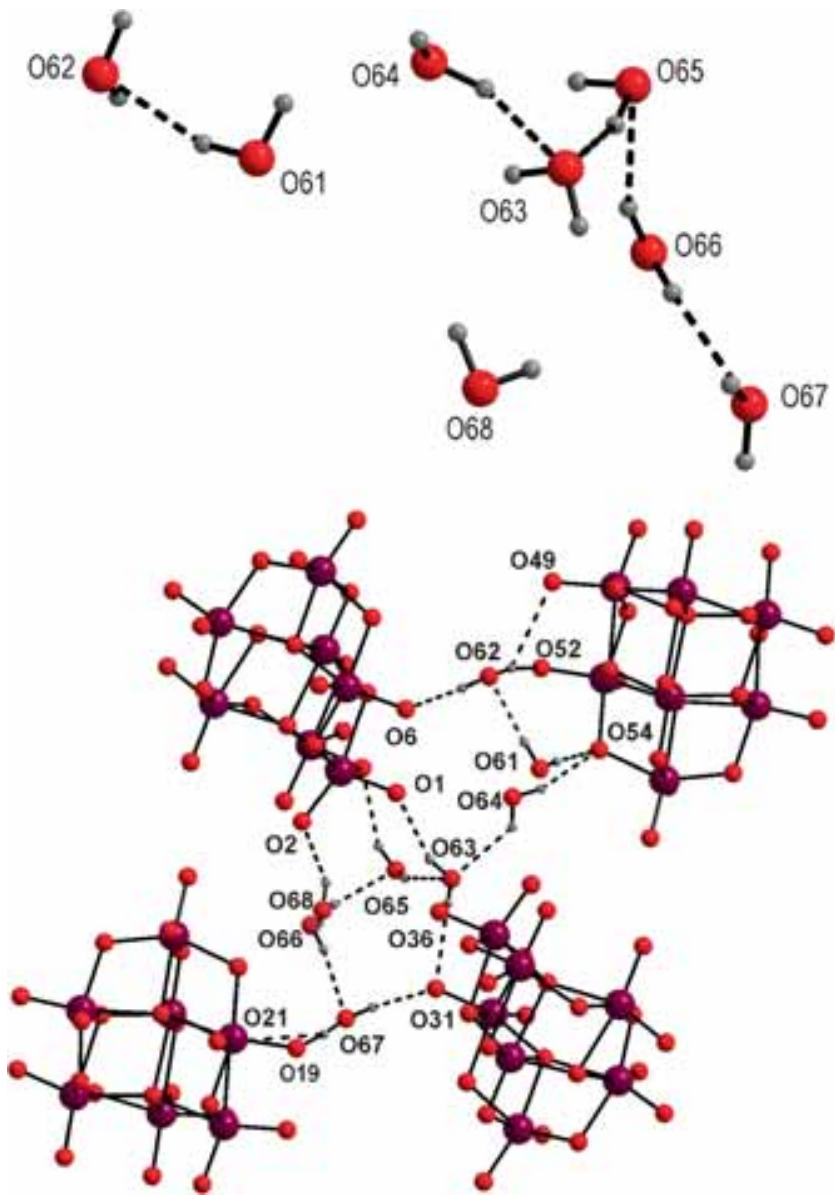

Figure 2. The H-bonding interactions among lattice water molecules in $\left(\mathrm{BuNH}_{3}\right)_{6}\left[\mathrm{Mo}_{7} \mathrm{O}_{24}\right] \cdot 4 \mathrm{H}_{2} \mathrm{O} \mathrm{1}$, showing the water dimer (O61 and O62) and water pentamer (O63, O64, O65, O66 and O67) (top). The lattice water molecules are linked to heptamolybdate anions via $\mathrm{O}-\mathrm{H}$. . O O bonding (bottom). (For symmetry relations, see Table 3 ).

the symmetric stretching vibration $\left(v_{1}\right)$ of the $\left(\mathrm{MoO}_{4}\right)^{2-}$ tetrahedron. ${ }^{36}$ Slow evaporation of the reaction mixture leads to the nucleation of crystals at $\mathrm{pH} \sim 8$. The 
Table 3. Geometrical parameters $\left(\AA,^{\circ}\right)$ of the $\mathrm{O}-\mathrm{H} \cdots \mathrm{O}$ interactions in $\mathbf{1}$.

\begin{tabular}{lcccccc}
\hline $\mathrm{D}-\mathrm{H}$ & $\mathrm{d}(\mathrm{D}-\mathrm{H})$ & $\mathrm{d}(\mathrm{H} \cdots \mathrm{A})$ & $<\mathrm{DHA}$ & $\mathrm{d}(\mathrm{D} \cdots \mathrm{A})$ & $\mathrm{A}$ & Symmetry codes \\
\hline O61-H1O & 0.840 & 2.00 & $2.834(4)$ & $2.834(4)$ & $\mathrm{O} 54$ & $-\mathrm{x}+1,-\mathrm{y}+1,-\mathrm{z}+1$ \\
O61-H2O & 0.840 & 2.04 & $2.853(4)$ & $2.853(4)$ & O62 & $-\mathrm{x},-\mathrm{y}+1,-\mathrm{z}+1$ \\
O62-H3O & 0.840 & 1.93 & $2.753(4)$ & $2.753(4)$ & O6 & \\
O62-H4O & 0.840 & 2.02 & $2.793(4)$ & $2.793(4)$ & O52 & $\mathrm{x}-1, \mathrm{y}, \mathrm{z}$ \\
O62-H4O & 0.840 & 2.59 & $3.110(4)$ & $3.110(4)$ & O49 & $\mathrm{x}-1, \mathrm{y}, \mathrm{z}$ \\
O63-H5O & 0.840 & 2.05 & $2.841(4)$ & $2.841(4)$ & O1 & \\
O63-H6O & 0.840 & 2.33 & $3.071(4)$ & $3.071(4)$ & O31 & $-\mathrm{x}+1, \mathrm{y}-1 / 2,-\mathrm{z}+3 / 2$ \\
O63-H6O & 0.840 & 2.53 & $3.155(5)$ & $3.155(5)$ & O36 & $-\mathrm{x}+1, \mathrm{y}-1 / 2,-\mathrm{z}+3 / 2$ \\
O64-H7O & 0.840 & 2.02 & $2.838(4)$ & $2.838(4)$ & O54 & $-\mathrm{x}+1,-\mathrm{y}+1,-\mathrm{z}+1$ \\
O64-H8O & 0.840 & 2.27 & $2.914(5)$ & $2.914(5)$ & O63 & $-\mathrm{x},-\mathrm{y}+1,-\mathrm{z}+1$ \\
O65-H9O & 0.840 & 2.2 & $2.977(4)$ & $2.977(4)$ & O4 & \\
O65-H10O & 0.840 & 2.08 & $2.866(6)$ & $2.866(6)$ & O63 & \\
O66-H11O & 0.840 & 2.16 & $2.989(6)$ & $2.989(6)$ & O67 & \\
O66-H12O & 0.840 & 2.02 & $2.813(7)$ & $2.813(7)$ & O65 & $-\mathrm{x}+1, \mathrm{y}+1 / 2,-\mathrm{z}+3 / 2$ \\
O67-H13O & 0.840 & 1.98 & $2.816(5)$ & $2.816(5)$ & O31 & \\
O67-H14O & 0.840 & 2.19 & $2.892(5)$ & $2.892(5)$ & O19 & \\
O67-H14O & 0.840 & 2.55 & $3.214(4)$ & $3.214(4)$ & O21 & \\
O68-H15O & 0.840 & 2.15 & $2.933(5)$ & $2.933(5)$ & O2 & $-\mathrm{x}+1, \mathrm{y}+1 / 2,-\mathrm{z}+3 / 2$ \\
\hline
\end{tabular}

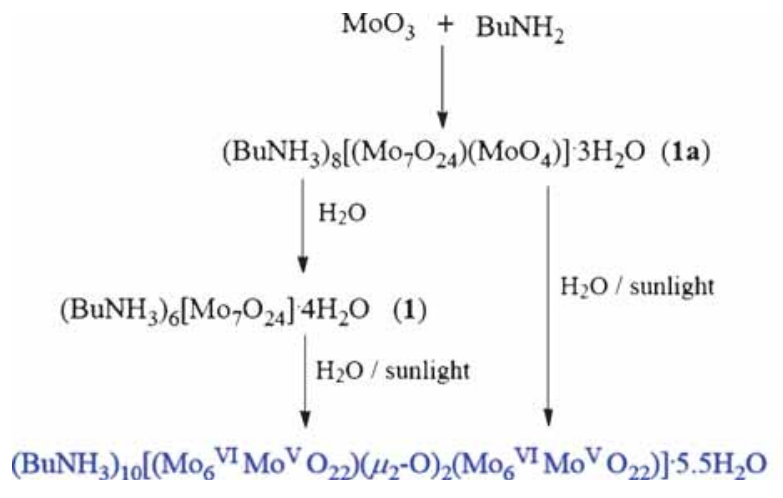

Scheme 1. Synthesis and photochemistry of $\left(\mathrm{BuNH}_{3}\right)_{6}$ $\left[\mathrm{Mo}_{7} \mathrm{O}_{24}\right] \cdot 4 \mathrm{H}_{2} \mathrm{O} \mathbf{1}$.

crystalline product, thus formed has been structurally characterized as a mixed mono-hepta compound namely $1 \mathrm{a}$ and not the butan-1-aminium salt of $\left(\mathrm{MoO}_{4}\right)^{2-}$ as reported earlier. ${ }^{10}$ In order to prepare a pure heptamolybdate devoid of $\left(\mathrm{MoO}_{4}\right)^{2-}$, several experiments were performed with the $\mathrm{MoO}_{3} / \mathrm{BuNH}_{2}$ system by varying temperature and stoichiometry. However, all these attempts were not fruitful to obtain a heptamolybdate as well as the product reported by Roman et al. ${ }^{16}$ All reactions resulted in the formation of only the mixed monohepta compound 1a. When crystals of 1a were taken in water, the $\mathrm{pH}$ of the reaction medium was found to be acidic ( $\mathrm{pH} \sim 6$ ). The Raman spectrum of the acidic reaction mixture (Figure S3) exhibits an intense signal at $939 \mathrm{~cm}^{-1}$ assignable for the symmetric stretching vibration of the $\left\{\mathrm{MoO}_{6}\right\}$ unit, giving a definite clue for the presence of $\left(\mathrm{Mo}_{7} \mathrm{O}_{24}\right)^{6-}$ ions in solution. Since heptamolybdates are generally isolated from acidic medium, ${ }^{35}$ compound $\mathbf{1 a}$ was dissolved in water and the reaction mixture was left aside for slow evaporation to isolate the product. The powder pattern of the product was found to be different from the starting 1a (Figure S4) indicating 1a loses its identity in water leading to its transformation to a new product. The X-ray structure analysis (vide supra), revealed it to be the desired pure heptamolybdate $\mathbf{1}$ in view of the absence of $\left(\mathrm{MoO}_{4}\right)^{2-}$ ion. The phase purity of the product was confirmed by a comparison of experimental X-ray powder pattern with that calculated from single crystal data (Figure S5).

The optical spectrum of $\mathbf{1}$ exhibits a strong absorption centred at around $208 \mathrm{~nm}$ (Figure S6) indicating the presence of heptamolybdate species. The IR spectrum of $\mathbf{1}$ shows several signals in the midIR region indicating the presence of organic moieties (Figure S7). The broad absorption seen around $3500 \mathrm{~cm}^{-1}$ in IR spectra of $\mathbf{1}$ can be attributed to the $\mathrm{O}-\mathrm{H}$ stretching vibration of lattice water. ${ }^{36} \mathrm{~A}$ signal appearing at around $3000 \mathrm{~cm}^{-1}$ can be assigned to the symmetric vibrations of the $\{\mathrm{N}-\mathrm{H}\}$ moiety of organic ammonium cation. In $\mathbf{1}$ the symmetric stretching mode of the $\left\{\mathrm{MoO}_{6}\right\}$ unit appears as an intense band in Raman spectrum at 939 $\mathrm{cm}^{-1}$ while the doubly degenerate asymmetric stretching mode occurs as a strong signal centred around 904 $\mathrm{cm}^{-1}$ in the IR spectrum. ${ }^{37} \mathrm{~A}$ doublet centred around 663 and $633 \mathrm{~cm}^{-1}$ can be attributed to (Mo-O-Mo) vibrations.

Thermal analysis of $\mathbf{1}$ did not show any mass loss till $\sim 100^{\circ} \mathrm{C}$. In the TG curve a decrease in mass of $4.60 \%$ accompanied by an endothermic event at $141^{\circ} \mathrm{C}$ in DTA curve (Figure 3 ) is observed. This can be attributed to the loss of four water molecules. Above $200^{\circ} \mathrm{C}$, the 


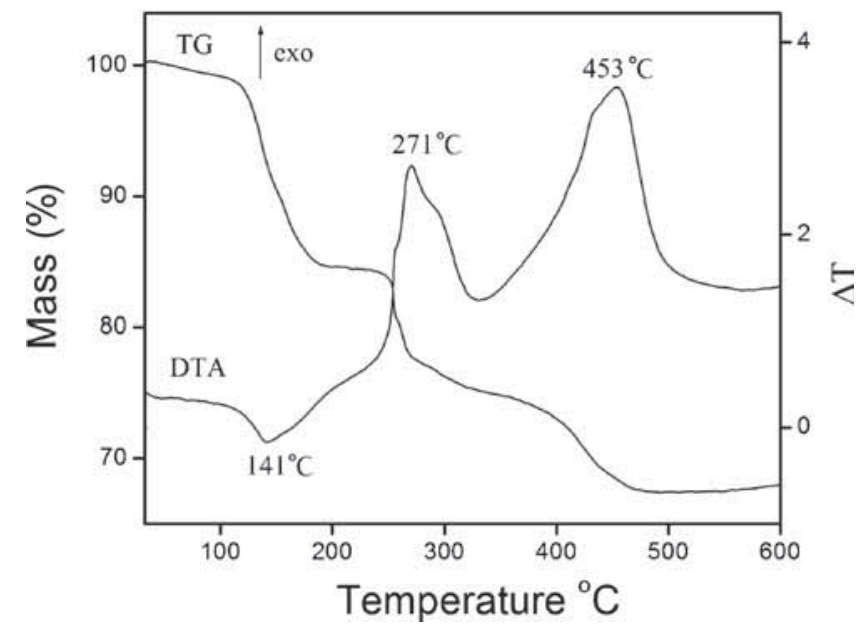

Figure 3. TG-DTA curves of $\left(\mathrm{BuNH}_{3}\right)_{6}\left[\mathrm{Mo}_{7} \mathrm{O}_{24}\right] \cdot 4 \mathrm{H}_{2} \mathrm{O} \mathbf{1}$.

DTA curve shows two exothermic peaks at 271 and $453^{\circ} \mathrm{C}$, respectively, which can be assigned to the decomposition of the anhydrous organic heptamolybdate, leaving a residue of $64.23 \%$. The residual mass obtained is in good agreement with the calculated residual mass (64.10\%) for a probable residual composition of $7 \mathrm{MoO}_{3}$. The results obtained are in accordance with the pyrolysis study of $\mathbf{1}$ carried out at $600^{\circ} \mathrm{C}$ in a furnace. The percentage residual mass obtained and its matching powder pattern with the reported orthorhombic $\alpha-\mathrm{MoO}_{3}$ (JCPDS No. 03-065-2421) presents good evidence for the formation of the phase pure $\alpha-\mathrm{MoO}_{3}$ (Figure 4). Based on satisfactory elemental analysis, spectral data and thermal studies, the composition of $\mathbf{1}$ is found to be 6:1:4 for organic cation:heptamolybdate:water.

An aqueous solution of $\mathbf{1}$ or the pristine solid does not undergo any detectable changes when kept under diffused light in the laboratory for extended periods of time. In contrast, an aqueous solution of 1 turns to intense blue under solar irradiation for $\sim 30 \mathrm{~min}$. This photochemical behaviour is very similar to that of $\mathbf{1 a}$. A comparison of the optical spectra of the blue solution obtained by irradiation of $\mathbf{1}$ and $\mathbf{1 a}$ reveals that both spectra are identical with absorption maxima at 610 and $734 \mathrm{~nm}$ (Figure S8 in Supplementary Information) indicating the presence of the same chromophore in both solutions. The blue product obtained by irradiation of 1a has been structurally characterized and shown to be a bis $\left(\mu_{2}\right.$-oxo $)$ bridged diheptamolybdate $\left(\mathrm{BuNH}_{3}\right)_{10}$ $\left[\left(\mathrm{Mo}_{6}^{\mathrm{VI}} \mathrm{Mo}^{\mathrm{V}} \mathrm{O}_{22}\right)\left(\mu_{2}-\mathrm{O}\right)_{2}\left(\mathrm{Mo}_{6}^{\mathrm{VI}} \mathrm{Mo}^{\mathrm{V}} \mathrm{O}_{22}\right)\right] \cdot 5.5 \mathrm{H}_{2} \mathrm{O} 1 \mathbf{b}$ and a detailed photochemistry of $\mathbf{1 a}$ has been described in our earlier report. ${ }^{10}$ Based on the synthetic protocol of 1 and the identical spectra of the irradiated products of 1 and 1a the formation of the blue solution can be explained as follows: When the mono-hepta compound

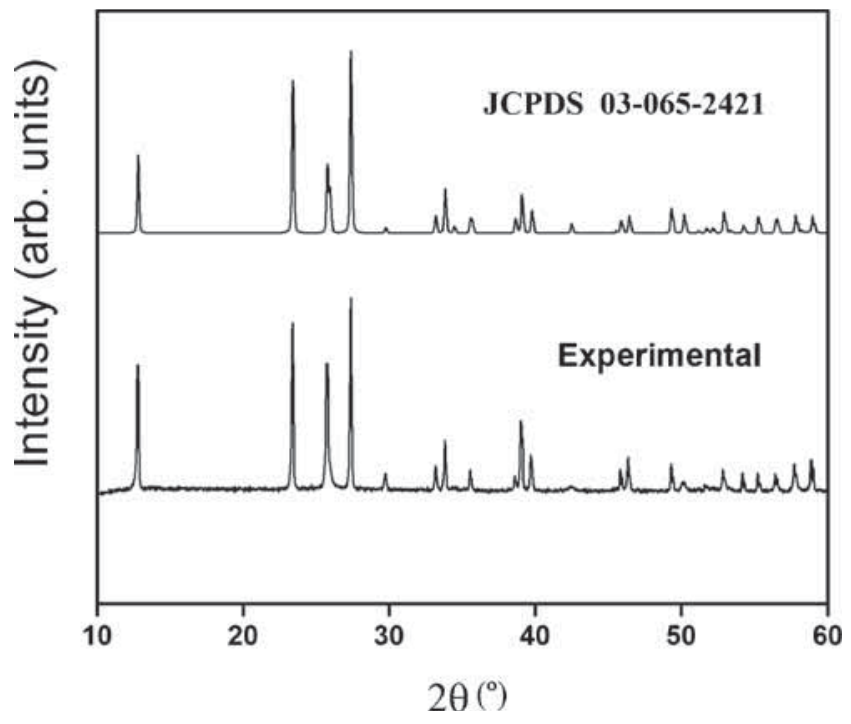

Figure 4. X-ray powder patterns of $\alpha-\mathrm{MoO}_{3}$ (JCPDS03-065-2421) and the residue obtained after pyrolysis of $\left(\mathrm{BuNH}_{3}\right)_{6}\left[\mathrm{Mo}_{7} \mathrm{O}_{24}\right] \cdot 4 \mathrm{H}_{2} \mathrm{O} 1$ at $600^{\circ} \mathrm{C}$.

1a is dissolved in water it first transforms to a pure heptamolybdate devoid of $\left(\mathrm{MoO}_{4}\right)^{2-}$ namely $\mathbf{1}$, which then dimerizes to the blue bis $\left(\mu_{2}\right.$-oxo $)$ bridged diheptamolybdate 1b (Scheme 1) under solar irradiation. Hence, we propose that compound $\mathbf{1}$ is an intermediate in the formation of the reduced bis( $\mu_{2}$-oxo $)$ diheptamolybate from 1a. The above proposal gains more credence from the electrochemical investigations of $\mathbf{1}$ and $\mathbf{1 a}$.

\subsection{Conductivity measurements and cyclic voltammetry}

The specific and molar conductivity data of aqueous solutions containing different concentrations of $\mathbf{1}$ and 1a (Table 4) exhibit a similar trend. The molar conductivity values show a steady increase with dilution indicating the facile dissociation of $\mathbf{1}$ and $\mathbf{1 a}$ in dilute solution, which is in accordance with the crystal structure of $\mathbf{1}$ and 1a showing discrete ions. The molar conductivity of $1\left[\left(\lambda_{\mathrm{m}}\right)(0.02 \mathrm{M}): 375 \mathrm{~S} \mathrm{~cm}^{2} \mathrm{~mol}^{-1}\right]$ is slightly less than that of $\left(\mathrm{NH}_{4}\right)_{6}\left[\mathrm{Mo}_{7} \mathrm{O}_{24}\right] \cdot 4 \mathrm{H}_{2} \mathrm{O}\left[\left(\lambda_{\mathrm{m}}\right)\right.$ $(0.02 \mathrm{M}): 525 \mathrm{~S} \mathrm{~cm}^{2} \mathrm{~mol}^{-1}$ ], but shows a pronounced decrease when compared with the $\lambda_{\mathrm{m}}$ of $\left(\mathrm{NH}_{4}\right)_{4}$ $\left[\mathrm{Li}_{2}\left(\mathrm{H}_{2} \mathrm{O}\right)_{7}\right]\left[\mathrm{Mo}_{7} \mathrm{O}_{24}\right] \cdot \mathrm{H}_{2} \mathrm{O}\left[\left(\lambda_{\mathrm{m}}\right)(0.02 \mathrm{M}): 1119 \mathrm{~S} \mathrm{~cm}^{2}\right.$ $\left.\mathrm{mol}^{-1}\right]^{34}$ and $\left(\mathrm{NH}_{4}\right)_{3}\left[\mathrm{Li}_{3}\left(\mathrm{H}_{2} \mathrm{O}\right)_{4}\left(\mu_{6}-\mathrm{Mo}_{7} \mathrm{O}_{24}\right)\right] \cdot 2 \mathrm{H}_{2} \mathrm{O}$ $\left[\left(\lambda_{\mathrm{m}}\right)(0.02 \mathrm{M}): 953 \mathrm{~S} \mathrm{~cm}^{2} \mathrm{~mol}^{-1}\right] .^{34}$ The conductivity data can be explained due to the different cations in these compounds. The observed data indicate that substitution of an ammonium ion by an organic ammonium cation does not affect the conductivity much unlike its substitution by a smaller $\mathrm{Li}^{+}$cation. It is interesting to note that an aqueous solution of $\mathbf{1}$ or $\mathbf{1 a}$ exhibits nearly identical molar conductivity despite the presence of eight organic cations and an $\left(\mathrm{MoO}_{4}\right)^{2-}$ ion 
Table 4. Specific conductivity $(\kappa)$ and molar conductivity $\left(\lambda_{\mathrm{m}}\right)$ data of 1 and $\mathbf{1 a}$.

\begin{tabular}{lcccc}
\hline $\begin{array}{l}\text { Molar } \\
\begin{array}{l}\text { Concentration } \\
(\mathrm{M})\end{array}\end{array}$ & $\begin{array}{c}\text { Specific conductivity }(\kappa) \\
\left(\text { in } \mathrm{S} \mathrm{cm}^{-1}\right)\end{array}$ & $\begin{array}{c}\text { Molar conductivity }\left(\lambda_{\mathrm{m}}\right) \\
\left(\mathrm{S} \mathrm{cm}^{2} \mathrm{~mol}^{-1}\right) \\
\mathbf{1 a}\end{array}$ \\
\hline 0.1 & 0.0125 & 0.0127 & $\mathbf{1}$ & 125 \\
0.08 & 0.0122 & 0.0123 & 152 & 127 \\
0.06 & 0.0117 & 0.0119 & 195 & 198 \\
0.04 & 0.0112 & 0.0113 & 280 & 282 \\
0.02 & 0.0075 & 0.0077 & 375 & 385 \\
\hline
\end{tabular}

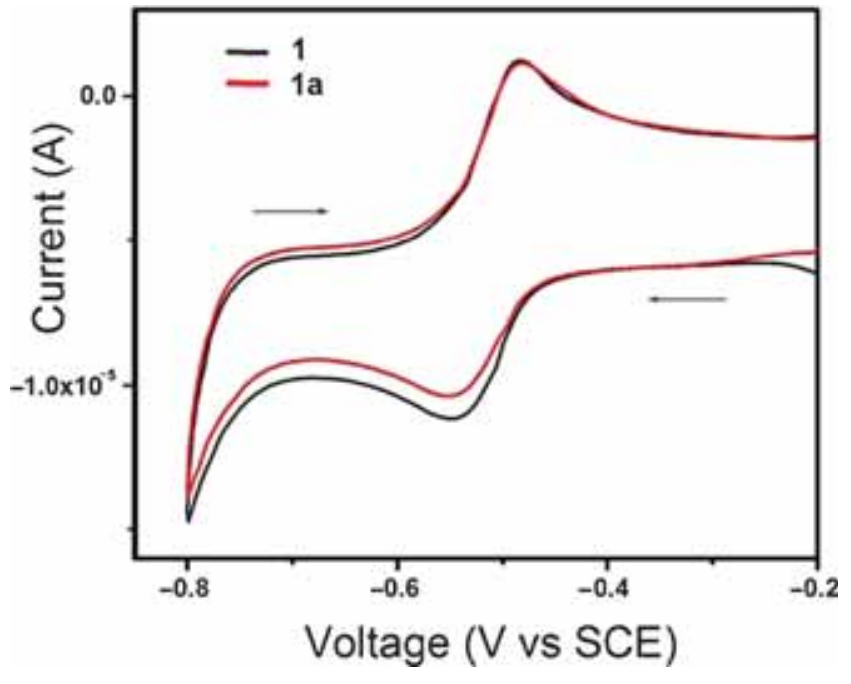

Figure 5. Cyclic voltammograms of $\left(\mathrm{BuNH}_{3}\right)_{6}\left[\mathrm{Mo}_{7} \mathrm{O}_{24}\right]$. $4 \mathrm{H}_{2} \mathrm{O} 1$ and $\left(\mathrm{BuNH}_{3}\right)_{8}\left[\left(\mathrm{Mo}_{7} \mathrm{O}_{24}\right)\left(\mathrm{MoO}_{4}\right)\right] \cdot 3 \mathrm{H}_{2} \mathrm{O} \mathbf{1 a}$ at a scan rate of $0.03 \mathrm{Vs}^{-1}$.

in the formula of 1a for each heptamolybdate unlike the six organic cations in $\mathbf{1}$ for each $\left[\mathrm{Mo}_{7} \mathrm{O}_{24}\right]^{6-}$. The similar conductivity data of aqueous solutions of $\mathbf{1}$ and 1a not only reveal the absence of $\left(\mathrm{MoO}_{4}\right)^{2-}$ in an aqueous solution of $\mathbf{1 a}$ but also confirm that the ionic species present in solution in both cases is one and the same viz., $\left(\mathrm{BuNH}_{3}\right)^{+}$and $\left[\mathrm{Mo}_{7} \mathrm{O}_{24}\right]^{6-}$.

The existence of only $\left[\mathrm{Mo}_{7} \mathrm{O}_{24}\right]^{6-}$ species in an aqueous solution of (1 or 1a) is further supported by the cyclic voltammetric study. All potentials in this work are referenced to the saturated calomel electrode (SCE). It is interesting to note that the current-voltage graphs of $\mathbf{1}$ and $\mathbf{1 a}$ are nearly identical (Figure 5) and both exhibit a single reversible redox event $\left(\mathrm{E}_{1 / 2}=-0.512 \mathrm{~V}\right)$ with a peak separation $\Delta \mathrm{E}=0.06 \mathrm{~V}$. The redox potential of $\mathbf{1}$ (or 1a) is quite comparable with those of other known heptamolybdates $\left(\mathrm{NH}_{4}\right)_{6}\left[\mathrm{Mo}_{7} \mathrm{O}_{24}\right] \cdot 4 \mathrm{H}_{2} \mathrm{O}\left(\mathrm{E}_{1 / 2}=\right.$ $-0.538 \mathrm{~V}),{ }^{34}\left(\mathrm{NH}_{4}\right)_{4}\left[\mathrm{Li}_{2}\left(\mathrm{H}_{2} \mathrm{O}\right)_{7}\right]\left[\mathrm{Mo}_{7} \mathrm{O}_{24}\right] \cdot \mathrm{H}_{2} \mathrm{O}\left(\mathrm{E}_{1 / 2}=\right.$ $-0.579 \mathrm{~V})^{34}$ and $\left(\mathrm{NH}_{4}\right)_{3}\left[\mathrm{Li}_{3}\left(\mathrm{H}_{2} \mathrm{O}\right)_{4}\left(\mu_{6}-\mathrm{Mo}_{7} \mathrm{O}_{24}\right)\right] \cdot 2 \mathrm{H}_{2} \mathrm{O}$ $\left(\mathrm{E}_{1 / 2}=-0.537 \mathrm{~V}\right)^{34}$ unlike the differing conductivity data. The observation of identical redox response in aqueous solutions of $\mathbf{1}$ and $\mathbf{1 a}$ serves to confirm the transformation of the mixed mono-hepta 1a to a pure heptamolybdate $\mathbf{1}$.

\section{Conclusions}

The investigations of the $\mathrm{MoO}_{3} / \mathrm{BuNH}_{2} /$ water reaction system reveal that $\mathrm{MoO}_{3}$ dissolves in aqueous $\mathrm{BuNH}_{2}$. Although the clear reaction mixture contains $\left(\mathrm{MoO}_{4}\right)^{2-}$ ions as evidenced by its Raman spectrum, slow evaporation results in the formation of a known mixed monohepta compound $\left(\mathrm{BuNH}_{3}\right)_{8}\left[\left(\mathrm{Mo}_{7} \mathrm{O}_{24}\right)\left(\mathrm{MoO}_{4}\right)\right] \cdot 3 \mathrm{H}_{2} \mathrm{O}$ $1 \mathrm{a}$ and not the butan-1-aminium salt of $\left(\mathrm{MoO}_{4}\right)^{2-}$. The title heptamolybdate charge balanced by $\left(\mathrm{BuNH}_{3}\right)^{+}$ cations and devoid of any $\left(\mathrm{MoO}_{4}\right)^{2-}$ can be crystallized as a tetrahydrate viz., $\left(\mathrm{BuNH}_{3}\right)_{6}\left[\mathrm{Mo}_{7} \mathrm{O}_{24}\right] \cdot 4 \mathrm{H}_{2} \mathrm{O} \mathbf{1}$ by dissolution of $\mathbf{1 a}$ in water. The crystal structure, spectral and thermal characteristics of $\mathbf{1}$ is reported. The identical photochemical behaviour of $\mathbf{1}$ and $\mathbf{1 a}$ to give a blue solution on irradiation and the identical conductivity and redox characteristics reveal that compound $\mathbf{1}$ is an intermediate in the formation of photodimerized bis $\left(\mu_{2}\right.$-oxo $)$ bridged diheptamolybdate $\mathbf{1 b}$ from $\mathbf{1 a}$.

\section{Supplementary Information (SI)}

Electronic supplementary information (for Figures S1-S8, Tables S1-S2) is available at www.ias.ac.in/ chemsci.

\section{Acknowledgements}

Financial assistance to the Department of Chemistry, Goa University at the level of DSA-I under the Special Assistance Programme (SAP) by the University Grants Commission, New Delhi is gratefully acknowledged.

\section{References}

1. Blazevic A and Rompel A 2016 Coord. Chem. Rev. $\mathbf{3 0 7}$ 42

2. Kortz U and Liu T 2013 Eur. J. Inorg. Chem. 2013 1556 
3. Cronin L and Müller A 2012 Chem. Soc. Rev. 417325

4. Salomon W, Lan Y, Rivière E, Yang S, Roch-Marchal C, Dolbecq A, Simonnet-Jégat C, Steunou N, LeclercLaronze N, Ruhlmann L, Mallah T, Wernsdorfer W and Mialane P 2016 Chem. Eur. J. 226564

5. Li S, Li Z, Ma H and Pang H 2016 J. Chem. Sci. 128825

6. Asnani M, Kumar D, Duraisamy $\mathrm{T}$ and Ramanan A 2012 J. Chem. Sci. 1241275

7. Srivani A, Venkateswara Rao T K, Sai Prasad S P and Lingaiah N 2014 J. Chem. Sci. 126467

8. Hmida F, Ayed M, Ayed B and Haddad A 2015 J. Chem. Sci. 1271645

9. Frenzel R A, Romanelli G P, Blanco M N and Pizzio L R 2015 J. Chem. Sci. 127123

10. Wutkowski A, Srinivasan B R, Naik A R, Schütt C, Näther C and Bensch W 2011 Eur. J. Inorg. Chem. 2254

11. Coue V, Dessapt R, Doeuff M B, Evain M and Jobic S 2007 Inorg. Chem. 462824

12. Pavani K and Ramanan A 2005 Eur. J. Inorg. Chem. 3080

13. Gutierrez-Zorrilla J M, Roman P, Esteban-Calderon C, Martinez-Ripoll M and Garcia-Blanco S 1984 Acta Crystallogr. Sect. A $\mathbf{4 0}$ C229

14. Roman P, Gutierrez-Zorrilla J M, Martinez-Ripoll M and Garcia-Blanco S 1986 Trans. Met. Chem. 11143

15. Ohashi Y, Yanagi K, Sasada Y and Yamase T 1982 Bull. Chem. Soc. Jpn. 551254

16. Roman P, Zorrilla J M G, Luque A and Martinez-Ripoll M 1988 J. Crystallogr. Spectrosc. Res. 18117

17. Roman P, San Jose A, Luque A and Zorrilla J M G 1994 Acta Crystallogr. C $\mathbf{5 0} 1031$

18. Niu J Y, You X Z, Fun H K, Zhou Z Y and Yip B C 1996 Polyhedron 151003

19. Roman $\mathrm{P}$, Gutièrez-Zorrilla $\mathrm{J} \mathrm{M}$, Martìnez-Ripoll $\mathrm{M}$ and Garcìa-Blanco S 1985 Z. Kristallogr. 173283
20. Roman $\mathrm{P}$, Luque $\mathrm{A}$, Aranzabe $\mathrm{A}$ and Gutièrez-Zorrilla J M 1992 Polyhedron 112027

21. Don A and Weakley T J R 1981 Acta Crystallogr. B37 451

22. Reinoso S, Dickman M H, Praetorius A and Kortz U 2008 Acta Cryst. E64 m614

23. Gili P, Lorenzo-Luis P A, Mederos A, Arrieta J M, Germain G, Castineiras A and Carballo R 1999 Inorg. Chim. Acta 295106

24. Arumuganathan T, Rao A S and Das S K 2010 Cryst. Growth Des. 104272

25. Khandolkar S S, Raghavaiah P and Srinivasan B R 2015 J. Chem. Sci. 1271581

26. Cruywagen J J, Esterhuysen M W and Heyns J B B 2003 Inorg. Chim. Acta 348205

27. Long D L, Kögerler P, Farrugia L J and Cronin L 2005 Dalton Trans. 1372

28. Arumuganathan T, Srinivasarao A, Kumar T V and Das S K 2008 J. Chem. Sci. 12095

29. Srinivasan B R and Morajkar S M 2016 Indian J. Chem. 55A 676

30. Yamase T 1991 J. Chem. Soc. Dalton Trans. 3055

31. Yamase T, Sasaki R and Ikawa T 1981 J. Chem. Soc. Dalton Trans. 628

32. Sheldrick G M 2015 Acta Crystallogr. C71 3

33. Lindqvist I 1950 Arkiv. Kemi. 2325

34. Khandolkar S S, Näther C, Bensch W and Srinivasan B R 2016 J. Coord. Chem. 691166

35. Srinivasan B R 2004 J. Chem. Sci. 116251

36. Nakamoto K 2009 In Infrared and Raman Spectra of Inorganic and Coordination Compounds Part A: Theory and Applications in Inorganic Chemistry 6th ed. (New Jersey: John Wiley)

37. Isaac M, Pradip T and Nayar V U 1994 J. Solid State Chem. 112132 